\title{
Article \\ Adaptation: A Vital Priority for Sustainable Water Resources Management
}

\author{
Elpida Kolokytha
}

check for

updates

Citation: Kolokytha, E. Adaptation:

A Vital Priority for Sustainable Water Resources Management. Water 2022, 14, 531. https://doi.org/10.3390/ w14040531

Academic Editor: Maria Mimikou

Received: 28 December 2021

Accepted: 5 February 2022

Published: 11 February 2022

Publisher's Note: MDPI stays neutral with regard to jurisdictional claims in published maps and institutional affiliations.

Copyright: (C) 2022 by the author. Licensee MDPI, Basel, Switzerland. This article is an open access article distributed under the terms and conditions of the Creative Commons Attribution (CC BY) license (https:// creativecommons.org/licenses/by/ $4.0 /)$.
Department of Civil Engineering, School of Engineering, Aristotle University of Thessaloniki, 54124 Thessaloniki, Greece; lpcol@civil.auth.gr

\begin{abstract}
Sustainability in terms of water management implies the study of all interrelated parameters (social, environmental, economic, engineering and political) in a comprehensive way. Although Greece is presented in the international rankings as a water-rich country, it has significant water problems due to its high temporal and spatial distribution of water resources and its unsustainable management practices characterized by a fragmented and sector-oriented water management system. This problem has been significantly improved by the adoption of the EU WFD and the development of management plans at the river basin scale. Nevertheless, because of the climate change effects, there is still a long way to go, and radical changes are needed in order to reach sustainability. Adaptation is a vital response toward sustainability. The Mygdonia agricultural basin is a case study of a highly negative water balance system that highlights the shortcomings of both water management and adaptation in Greece. Analysis of the hydrology of the basin, as well as the climate projections until 2100, revealed the urgent need for concerted action. A set of different development adaptation strategies was applied and assessed concerning their effectiveness. According to the outputs of this research, integrated watershed management is a prerequisite for a successful adaptation policy. Radical reform is needed in the agricultural sector by decreasing the agricultural land and changing crops. Demand management is the solution rather than focusing on supply options.
\end{abstract}

Keywords: climate crisis; water adaptation; Greece; Koronia lake; sustainability; Mygdonia Basin

\section{Introduction}

The scientific question on whether the observed recent climate changes are anthropogenic or exclusively natural occurring over time as the natural cycle of climate change has been the subject of several studies in the last few decades [1-3].

The Intergovernmental Panel on Climate Change (IPCC) has recently released the Physical Science Basis report (August 2021), where it is documented that "climate change is already affecting nearly every part of the planet, and human activities are unequivocally the cause" [4]. It is imperative to immediately take action.

Regardless of the main reasons, what the whole scientific community agrees on is that climate change exists and that a new reality is here to be dealt with.

Water is the most vital component of life and is critical for almost all economic activities; as such, it is central to the achievement of sustainable development. The Global Risks Report of 2020 ranks environmental issues (among them, extreme weather events natural disasters, water crisis, failure regarding climate action) first on a list of the top global risks in terms of the impact on humanity [5]. According to the UN, climate change is projected to increase the number of water-stressed regions and exacerbate shortages in already water-stressed regions [6]. Alteration of the water cycle (quantity and quality) and an increase in extremes events are major impacts of climate change on freshwater resources. The planet will face a $40 \%$ shortage in water supply by 2030 . Hydrological disasters, floods and storms accounted for $44 \%$ and $28 \%$, respectively, of all disaster events from 2000 to 2019, affecting 1.6 billion people worldwide [5]. 
Climate change is characterized by great uncertainty, affecting the development model of a country directly and decisively, with significant differences in time and space at all levels, namely, local, regional, national and global. In order to reverse or halt the severe consequences of the current climate crisis, we need to work collectively and understand the depth and complexity of this crisis. Two types of responses for climate crisis mitigation and adaptation need to be applied concurrently. Mitigation [7] addresses the root cause of climate change (accumulation of greenhouse gases in the atmosphere), whereas adaptation addresses the impacts of climate change. Adaptation, in brief, anticipates the adverse effects of climate trends and takes appropriate action to prevent or minimize the damage they can cause [8-15]. Since mitigation reduces the rate, as well as the magnitude, of the root cause (warming), it also increases the time available for adaptation to a particular level of the climate crisis.

In the 21st century, "a new global theory" for water and its management is needed. Until recently, the hydrologic record of the past was the best guide for the future [16]. However, due to the increase in the rate of extreme events, as well as the non-stationarity and the great vulnerability and uncertainty in hydrological projections, we need to move from a solely technical and engineering management of water to a clear understanding of the complicated links between land, forest, agriculture, biodiversity, energy, health and true integration of the human dimension. We need to make water management more adaptive and flexible to be operational under fast-changing global socio-economic and climate-sensitive conditions $[17,18]$. A major issue in this effort is the reassessment of the global consumption and production model to manage food security, water scarcity and sustainable development through effective adaptations in agriculture.

In their quest for sustainable development, policymakers have to make trade-offs between the benefits and costs of adaptation measures, opinions on how much risk is socially acceptable and other development objectives $[19,20]$.

The objective of the current research was to assess the climate impacts on water management in basins with severe water deficits by providing a better understanding of the adaptation options at a local level. More specifically, demand and supply adaptation strategies are explored in river basins with negative water balances and intense agricultural activity. The implementation of adaptation options was achieved by using a comprehensive analysis of both hydrologic and water management methods. This approach amplified the premises of sustainability, reflected new paradigms and practices and explained the opportunities for innovative approaches in water resources management. The case study of Mygdonia Basin was used as a representative example, as it is a highly water-stressed agricultural basin with an already negative water regime. Similar cases are encountered, both in other basins in Greece and in the Mediterranean. This article can act as a useful decision-making tool for policymakers to implement adaptation solutions to manage water resources, taking into account climate impacts in the area under study in a sustainable way.

\section{Materials and Methods}

\subsection{Water Resources and Uses in Greece}

Greece is located in the eastern part of the Mediterranean Basin, with the most extensive coastline in Europe of $15,000 \mathrm{~km}$ along the Mediterranean Sea. The climate is characterized by mild and rainy winters, relatively warm and dry summers and long sunshine duration almost all year long. Although the country is claimed to have adequate water reserves at $6471 \mathrm{~m}^{3} /$ capita/year [21], it suffers from a high temporal and spatial distribution of the water supply, which causes significant water shortages in specific regions in Greece [22,23]. The particular geomorphological conditions with the wet mountainous region concentrated along the backbone of the country, the rather dry long coastline and the numerous islands scattered in the Ionian and Aegean seas are responsible for the uneven distribution of the water supply. As a result, plentiful water can be found in the mountains flowing into the sea creating small torrents and rivers during winter, with almost no flow during summer in the dry period [24]. Moreover, there is high spatial and temporal water 
demand. Greece is an agricultural country, with $84 \%$ of its consumption belonging to the agricultural sector, with strong tourism in the islands and high seasonal water demand in the summer. High urbanization, with half of the population concentrated in two cities (Athens and Thessaloniki), where competition for water for economic activities is high, is another reason for the temporal and spatial water demand in Greece. Furthermore, the dependence of the country on the $16-20 \%$ of waters imported by four transboundary rivers reveals the extent of the water problem.

\subsection{Demand Management versus Supply Management}

Demand management has gone largely unaddressed in Greece since most water services focused on infrastructure development rather than on water conservation. This supply-oriented water policy for all these years was based on the "notion" that the solution to the water problem relies unilaterally on the country's capacity for engineering solutions to divert, construct and bring water to where it is needed, no matter how far and how costly this may be, has resulted in negative water balances and the depletion of groundwater reserves in many basins (Central Macedonia, Thessaly, Aegean Islands) [25]. Moreover, tools such as water pricing, especially in the agricultural sector, were only considered a viable option under the condition that all other supply options were exhausted, and overexploitation of surface and groundwater resources had resulted in water depletion. This hydrological reality, together with the fact that climate change will deteriorate the water reserves, calls for a drastic change in managing water for all uses. In such cases of drained water basins, the efficacy of measures that reduce/limit the use of water is questionable. It is highly likely that more drastic measures need to be taken, such as a change in the relevant economic activities and the suspension of the most water-consuming activities among them.

\subsection{Water Climate Impact Projections in the Mediterranean and Greece}

The Mediterranean Basin is a region that is already greatly affected by climate change [26], which is expected to remain among the "hotspot" regions most affected by climate change in the future, particularly when it comes to precipitation and the hydrological cycle [27-30]. The climate is changing in the Mediterranean Basin faster than global trends [26]. It is expected that heat waves will intensify in duration and peak temperatures, as well as heavy rainfall events, are likely to also intensify by $10-20 \%$ in all seasons except summer [31,32]. Precipitation and temperature changes are expected to increase crop water requirements [33] while putting food security in peril [34].

Despite strong regional variations, summer rainfall will likely be reduced by 10 to $30 \%$ in some regions, increasing existing water shortages and desertification and decreasing agricultural productivity [33,35]. As a typical Mediterranean country, Greece will experience these impacts. Water resources seem to be particularly affected by climate change in Greece, as it is reported that Greece ranked 26th among the countries that experienced severe water stress in 2019 and this water stress is highly likely to get worse by 2050 [36].

The Bank of Greece [37] published a detailed assessment of climate projections over Greece. In this report, in order to capture the possible changes in the water potential of the country until the year 2100, hydrological balance components were estimated for the periods of 2021-2050 and 2071-2100 using the emission scenarios A1B, A2 and B2. Details on the emission scenarios can be found in [6]. The results indicated significant changes in the hydrological components for each possible scenario. Specifically, the comparison regarding the changes in rainfall volume and total water potential (surface runoff and groundwater discharge) per climatic scenario in the whole Greek territory under current and future conditions predicted a reduction in rainfall ranging between $3 \%$ to $7 \%$ and a total water potential reduction (surface runoff and groundwater discharge) by 7-20\% for the period of 2021-2050. Concerning the period of 2071-2100, the reduction will continue and most probably will be even higher, ranging from $14 \%$ to $22 \%$ regarding rainfall and between $30-54 \%$ regarding the water potential for the whole country [37]. These findings 
are in line with the IPCC 2014 report, which predicted (based on climate model A1B) that in the eastern part of the Mediterranean Basin (where Greece is located), rainfall in 2080-2099 will show a decrease of more than 20\% compared with the period of 1980-1999. Furthermore, the annual precipitation is expected to decrease in most Mediterranean areas, including Greece, with the annual number of precipitation days being decreased. It is noted that the risk of summer drought is expected to rise, especially in southern Greece, while the duration of the snow season is very likely to be shorter $[38,39]$.

In relation to temperature, according to the IPCC 2014 report, the annual mean temperatures, as well as the evapotranspiration in Greece, are likely to increase more than the global mean, especially regarding maximum summer temperatures.

In Greece, an increase in irrigation and tourist needs, as well as in the pollution load, is expected in the near future [37,40]. Vulnerability to climate change for the period 2050-2100 in comparison with the period 1961-1990 was also assessed. Greece shows a high vulnerability in Central Macedonia and the Western Peloponnese and moderate vulnerability in Thrace, Thessaly, Attica and Rhodes [41-44].

It is evident that the already disturbed water balances in the water basins in Greece will be further accelerated based on the future projections of climate impacts. Obviously, as precipitation has a strong local/regional component, this acceleration will have different results and will be shown first in the most vulnerable regions.

\subsection{The Mygdonia Water Basin}

Mygdonia Basin is located in Central Macedonia, $11.5 \mathrm{~km}$ northeast of the city of Thessaloniki. It occupies an area of $2061.48 \mathrm{~km}^{2}$, with a population of approximately 65,000 inhabitants (ELSTAT2011), and hydrologically belongs to the Water District of Central Macedonia (GR10). It is surrounded by mountains with an altitude of 600-1200 m and the climate is a typical Mediterranean one. The surface flow is seasonal coming from distributed streams in winter, whereas during the dry season, their flow is reduced or almost non-existent.

Mygdonia Basin is a protected wetland according to the Ramsar Convention, with a complex water system comprising Lake Koronia (western part of the basin, $1278 \mathrm{~km}^{2}$ ), Lake Volvi (eastern part of the basin $783.48 \mathrm{~km}^{2}$ ) and the Mygdonia groundwater aquifer (Figure 1). The Ramsar Convention encourages the designation of sites containing representative, rare or unique wetlands or wetlands that are important for conserving biological diversity. The Koronia and Volvi wetlands support endemic fish, nesting waterbirds and large numbers of wintering birds, including Anatidae (geese, ducks, swans, etc.). Several nationally rare or endangered aquatic plants also occur here [45].

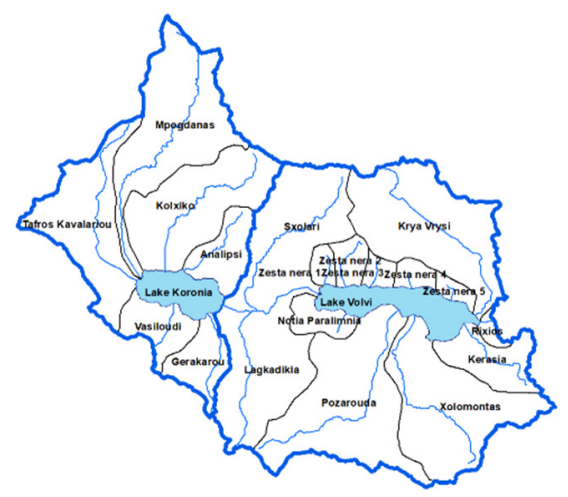

Figure 1. Map of the reference area provided by Malamatatis D. in his PhD.

The mild climate and the fertile soil favor irrigation of these lands and have contributed to the rapid development of agriculture. The economy of the area consists of small local enterprises serving the needs of the local communities. Besides agriculture, residents are mainly employed in livestock, while the secondary section of the economy mainly 
involves wood and construction enterprises. This information is given by the responsible Koronia-Volvi Management Body.

The overflow of Lake Koronia drains into Lake Volvi through the Derveni stream (Figure 1). The overflow of Lake Volvi drains into the Strymonikos Gulf through the Richios stream. The groundwater flows from the Koronia sub-catchment to the Volvi sub-catchment, and then a part of this discharge outflows to Lake Volvi and another one outflows to the Strymonikos Gulf. There is no flow interaction between the groundwater and Lake Koronia, as the bottom of the lake is impermeable [46].

It is a predominantly agricultural water basin in the Mediterranean region, with 95\% of the basin's water being used for agricultural purposes [45], which suffers from unsustainable water management practices. During the last few decades, Lakes Volvi and Koronia, along with the Mygdonia Basin aquifer, have undergone severe quantitative and qualitative degradation due to past industrial, agricultural and urban activities. In particular, the water depth of Lake Koronia has progressively decreased since 1970, resulting in complete depletion in the summer of 2008. Lake Volvi, as a larger and deeper lake compared with Lake Koronia, experienced a smaller reduction of its depth. Moreover, the limited recharge to the Mygdonia Basin aquifer and the over-pumping for irrigation caused a significant drawdown of the groundwater table [47]. Central Macedonia (GR10) faces groundwater quantity pressure, as about $25 \%$ of the groundwater bodies are characterized to be in a poor/bad quantity state [44].

The environmental problems of the Mygdonia Basin were initially recognized in 1995 when an episode of mass fish deaths took place in Lake Koronia. The environmental collapse of Lake Koronia resulted in the drafting of the "Master Plan for the restoration of Lake Koronia" in 1998. The Master Plan had been oriented toward large-scale infrastructures and a water transfer scheme from the River Aliakmon, which flows in a neighboring catchment. Several of the proposed solutions in the Master Plan raised objections from both the central administration and international institutions since they were hard engineering projects that would cause considerable environmental impacts in the area, mainly altering the Ramsar protected ecosystem and the hydrodynamics of the water systems. In 2004, a "Revised Restoration Plan of Lake Koronia" was carried out to review the first Master Plan.

The overexploitation of the surface water system (Lakes Koronia and Volvi) and groundwater resources during the previous decades, along with the projected decrease in the future water availability due to climate change, indicate the need to highly prioritize concerted action toward adaptation to climate change in the Mygdonia water system [48-50]. Research on Mygdonia Basin is limited and mainly concerns Lake Koronia, although there are some studies on Lake Volvi that mostly focused on water quality issues [51-56]. Some attempts were made to address simulations the restoration of the water balance of the hydrological basin of Lake Koronia by Manakou [57], while Zalidis [58] and Zalidis et al. [59] studied the Master Plan for the restoration of Lake Koronia. Kolokytha [60-63] examined the impact of WFD and EU CAP and the water footprint of crops in the Lake Koronia basin. Veranis [46] studied the hydrogeology of Mygdonia Basin, while the perspectives of the exploitation of the deep aquifer for the restoration of the Lake Koronia were examined by Mylopoulos et al. [64,65]. Our group has tried an integrated approach that investigated the impacts of climate change in the whole Mygdonia water system (conjunctive use of surface and groundwater resources) and the economy of the region $[47,49,66]$.

\subsection{Methodology}

$>$ First, a fully integrated hydrological analysis of the Mygdonia Basin for historical and future periods was carried out. Future climatic data were derived and analyzed from the SMHIRCA Regional Climate Model (chosen among MPI-M-REMO and METOHC_HardRM3Q0 as the most credible to simulate the $\mathrm{P}$ and $\mathrm{T}$ of historical data), while climate change impacts on the water balance of both lakes and the Mygdonia Basin aquifer (conjunctive management of surface and groundwater resources) until 2100 were projected by developing a modeling system that included coupled hydrological 
and hydraulic models, namely, UTHBAL $[67,68]$ MIKE SHE, MIKE HYDRO River and MIKE HYDRO Basin [69-71]. Details can be found in Malamataris et al. [47].

The final outputs of the modeling system (Figure 2) included the future water balance of the Mygdonia Basin aquifer and the Lakes Koronia and Volvi, as well as the piezo-metric surface and the water level, surface area and stored volume of the lakes until 2100. Details can be found in Malamataris et al. [47].

$>\quad$ By using the information of the previous hydrological analysis, three sustainable development strategies were formed that combined different adaptation measures seeking sustainable solutions for the restoration of the water system and the development of the area. The results were published in Kolokytha et al. [49]. Some of the results are discussed in this work as an example of adaptation to climate change in water systems with a high negative water balance.

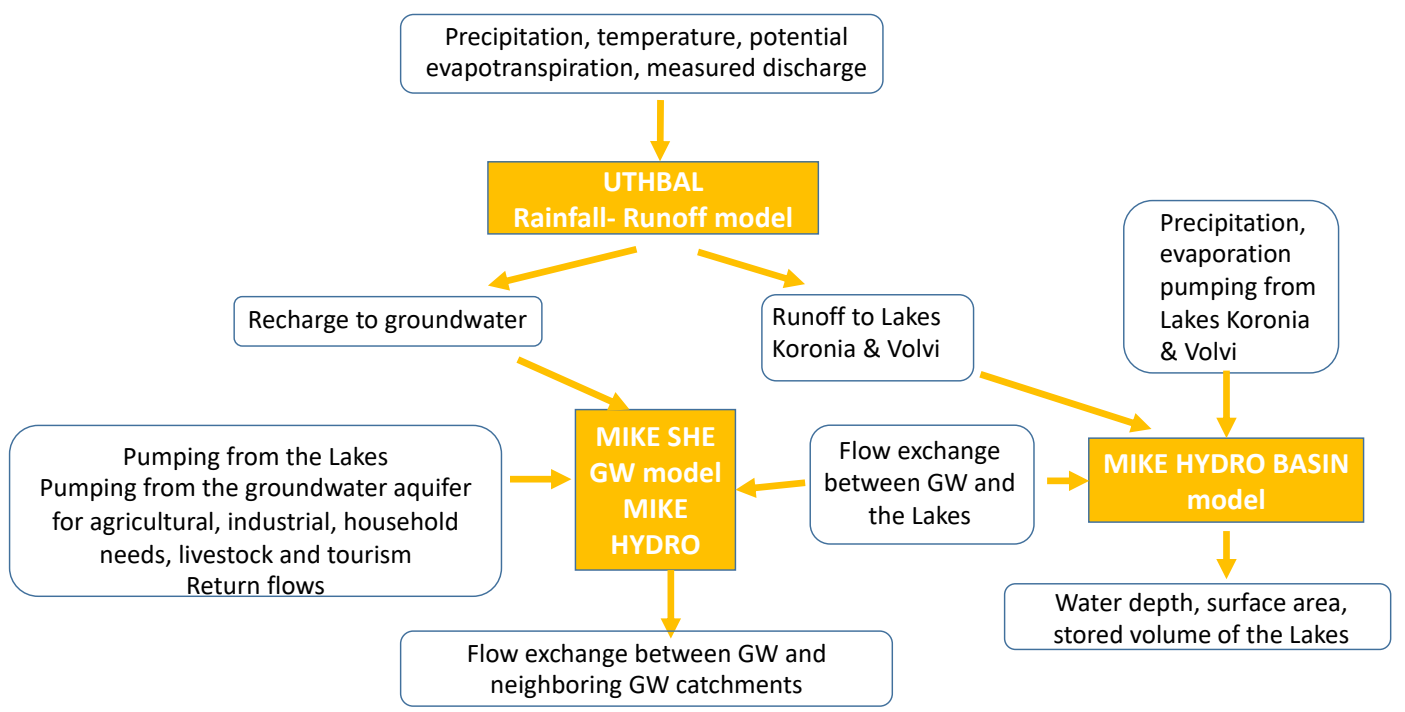

Figure 2. The developed integrated modeling system applied in the Mygdonia Basin that was modified, adopted by Malamataris D. et al. [47]. GW refers to groundwater.

\section{Results}

In the last few decades, the water balance of Mygdonia Basin has been constantly negative as a result of the fact that water consumption has been constantly exceeding the natural recharge in the basin. From the study of the water balance of the Mygdonia water system, taking into account the historical reference data (1970-2000) and climate projections, it is evident that the water balance is getting worse as the rainfall is anticipated to further decrease (between $-5.45 \%$ (period $2020-2050)$ to $-17.99 \%$ (2050-2080)). Tables $1-3$ summarize and reveal the extent of the water problem. The year 2010 was selected to be the starting year for the future climate and hydraulic study because of the lack of measured meteorological data for the period 2000-2010. The small improvement in the groundwater balance during the 2010-2040 period was mainly credited to the significant reduction in the groundwater withdrawals for industrial use due to the shutdown of industries. The vast majority of the industries that were under operation during the historical reference period are currently inactive, mainly because of the pumped water limitations that were specifically established for the Mygdonia catchment. The total amount of pumped water for industrial use is estimated to be reduced by $90 \%$ compared with the historical period. 
Table 1. Mean water balance of Mygdonia aquifers ( $\mathrm{hm}^{3} /$ year).

\begin{tabular}{|c|c|c|c|c|c|}
\hline & & 1970-2000 & 2010-2040 & 2040-2070 & 2070-2100 \\
\hline \multirow{5}{*}{$\begin{array}{l}\text { Inflows to Mygdonia } \\
\text { aquifers (hm³/year) }\end{array}$} & Recharge & 129.33 & 127.58 & 87.95 & 80.67 \\
\hline & $\begin{array}{l}\text { Return flow of the pumped } \\
\text { water for irrigation use }\end{array}$ & 24.85 & 25.49 & 28.84 & 30.87 \\
\hline & Inflow from Lake Koronia & 0.00 & 0.00 & 0.00 & 0.00 \\
\hline & Inflow from Lake Volvi & 0.66 & 2.25 & 2.76 & 3.72 \\
\hline & $\begin{array}{l}\text { Inflow from the neighboring } \\
\text { groundwater aquifer }\end{array}$ & 0.00 & 0.00 & 0.35 & 2.01 \\
\hline \multirow{8}{*}{$\begin{array}{l}\text { Outflows from Mygdonia } \\
\text { aquifers ( } \mathrm{hm}^{3} \text { / year) }\end{array}$} & Outflow for agricultural use & 164.94 & 167.51 & 189.85 & 203.39 \\
\hline & Outflow for industrial use & 7.33 & 0.73 & 0.73 & 0.73 \\
\hline & Outflow for livestock use & 1.86 & 1.86 & 1.86 & 1.86 \\
\hline & Outflow for household use & 6.40 & 6.40 & 6.40 & 6.40 \\
\hline & Outflow for tourist use & 0.02 & 0.02 & 0.02 & 0.02 \\
\hline & Outflow to Lake Koronia & 0.00 & 0.00 & 0.00 & 0.00 \\
\hline & Outflow to Lake Volvi & 0.41 & 0.03 & 0.03 & 0.00 \\
\hline & $\begin{array}{l}\text { Outflow to the neighboring } \\
\text { groundwater aquifer }\end{array}$ & 1.35 & 1.31 & 0.28 & 0.00 \\
\hline \multicolumn{2}{|c|}{ Mean water balance of Mygdonia aquifers ( $\mathrm{hm}^{3} /$ year) } & -27.47 & -22.54 & -79.27 & -95.13 \\
\hline
\end{tabular}

Table 2. Mean water balance of Lake Koronia ( $\mathrm{hm}^{3} /$ year).

\begin{tabular}{|c|c|c|c|c|c|}
\hline & & 1970-2000 & 2010-2040 & 2040-2070 & 2070-2100 \\
\hline \multirow{3}{*}{$\begin{array}{l}\text { Inflows to the lake } \\
\text { Koronia ( } \mathrm{hm}^{3} \text { / year) }\end{array}$} & Precipitation & 20.61 & 19.74 & 17.05 & 16.29 \\
\hline & $\begin{array}{l}\text { Runoff from the } \\
\text { watershed }\end{array}$ & 10.90 & 15.50 & 12.13 & 11.33 \\
\hline & $\begin{array}{l}\text { Inflow from the } \\
\text { groundwater aquifer }\end{array}$ & 0.00 & 0.00 & 0.00 & 0.00 \\
\hline \multirow{5}{*}{$\begin{array}{l}\text { Outflows from Lake } \\
\text { Koronia ( } \mathrm{hm}^{3} / \text { year) }\end{array}$} & Evaporation & 38.24 & 33.86 & 29.49 & 28.09 \\
\hline & Pumping from the lake & 0.00 & 0.00 & 0.00 & 0.00 \\
\hline & $\begin{array}{l}\text { Outflow to the } \\
\text { groundwater aquifer }\end{array}$ & 0.00 & 0.00 & 0.00 & 0.00 \\
\hline & $\begin{array}{l}\text { Overflow to the Derveni } \\
\text { stream }\end{array}$ & 0.22 & 0.00 & 0.00 & 0.00 \\
\hline & $\begin{array}{c}\text { Mean water balance of } \\
\text { Lake Koronia }\left(\mathrm{hm}^{3} / \text { year }\right)\end{array}$ & -6.95 & +1.38 & -0.31 & -0.47 \\
\hline
\end{tabular}

In the Mygdonia Basin, different supply- and demand-oriented measures were tested. The supply-oriented measures focused on stream diversion and reservoir construction to enhance the water potential of the water system, which was found to be inadequate to restore the degraded water system. Details can be found in [47].

Three Sustainable Development Strategies (SDS) were formed via the combination of some demand management measures to reduce water use and improve water efficiency through the restructuring of crops and changing irrigation systems based on different local, regional, national and international policies.

In the Mygdonia Basin, the dominant crop is cereal, which is a rain-fed crop, and thus does not negatively affect the water balance of the basin. Maize and alfalfa are the highest water-intensive crops and provide high farm income. Low-water-intensive crops, such as cereals and animal feed, provide low farm income. The area per type of crop from data 
by the Regional Administration of Central Macedonia in the Mygdonia Basin is depicted in Figure 3. From the net agricultural income per crop from data of the Greek Ministry of Environment, Energy and Climate Change (POL1077/2014), the current annual total net farm income in the whole Mygdonia Basin is estimated to be equal to EUR 45,773,037.90.

Table 3. Mean water balance of Lake Volvi ( $\mathrm{hm}^{3} /$ year).

\begin{tabular}{|c|c|c|c|c|c|}
\hline & & 1970-2000 & 2010-2040 & 2040-2070 & $2070-2100$ \\
\hline \multirow{4}{*}{$\begin{array}{l}\text { Inflows to Lake Volvi } \\
\left(\mathrm{hm}^{3} / \text { year }\right)\end{array}$} & Precipitation & 31.61 & 31.99 & 27.27 & 25.94 \\
\hline & $\begin{array}{c}\text { Runoff from the } \\
\text { watershed }\end{array}$ & 20.92 & 15.82 & 14.65 & 13.79 \\
\hline & $\begin{array}{l}\text { Inflow from the } \\
\text { groundwater aquifer }\end{array}$ & 0.41 & 0.03 & 0.03 & 0.00 \\
\hline & $\begin{array}{l}\text { Inflow from the Derveni } \\
\text { stream }\end{array}$ & 0.22 & 0.00 & 0.00 & 0.00 \\
\hline \multirow{4}{*}{$\begin{array}{l}\text { Outflows from Lake Volvi } \\
\qquad\left(\mathrm{hm}^{3} / \text { year }\right)\end{array}$} & Evaporation & 54.69 & 48.57 & 38.72 & 34.99 \\
\hline & Pumping from the lake & 0.70 & 2.40 & 2.40 & 2.40 \\
\hline & $\begin{array}{l}\text { Outflow to the } \\
\text { groundwater aquifer }\end{array}$ & 0.66 & 2.25 & 2.76 & 3.72 \\
\hline & $\begin{array}{l}\text { Outflow to the Richios } \\
\text { stream }\end{array}$ & 0.00 & 0.13 & 0.00 & 0.00 \\
\hline \multicolumn{2}{|c|}{ Mean water balance of lake Volvi (hm ${ }^{3}$ /year) } & -2.89 & -5.51 & -1.93 & -1.38 \\
\hline
\end{tabular}

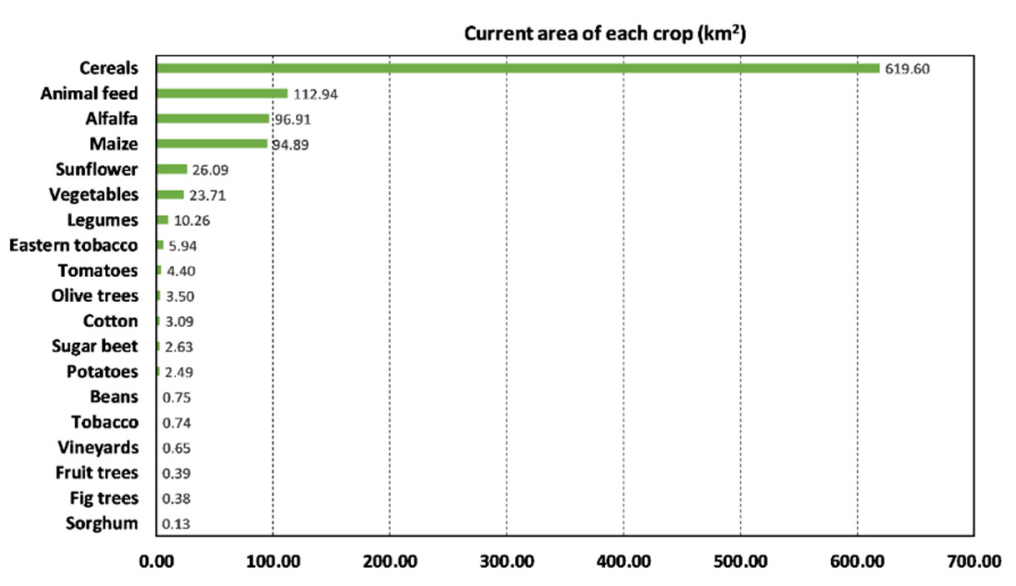

Figure 3. The area of each crop in the Mygdonia Basin.

The three Sustainable Development Strategies tested are:

1. The reduction of the total irrigated agricultural area (SDS1) related to a national priority (NP), the Rural Development Plan 2014-2020 of Greece and the EU Common Agricultural Policy, according to which, the fallow land measure was proposed to be applied to at least $30 \%$ of the irrigated area, while in the set-aside land, all types of agricultural activities are prohibited. In particular, the fallow land measure was proposed to be applied to all kinds of irrigated crops in the study area with the exception of tree plantations and vineyards, which are multiannual crops. Following a trial-and-error method, it was found that the minimum percentage of the irrigated land of the Mygdonia Basin that should be set aside in order to achieve a water surplus of Mygdonia aquifers is equal to 33\% and 61\% for the short-term (2020-2050) and long-term (2050-2080) future periods, respectively. By applying the proposed SDS1, the irrigation water demand was projected to decrease from $178.38 \mathrm{hm}^{3}$ /year to $119.50 \mathrm{hm}^{3} /$ year in the 2020-2050 period and from $192.91 \mathrm{hm}^{3} /$ year to $75.38 \mathrm{hm}^{3} /$ year 
in the 2050-2080 period. If SDS1 is applied, the farmers' incomes will have a reduction from EUR 45,773,037.90 to EUR 35,395,528.60 in the short term (2020-2050) and EUR $26,587,206.00$ in the long term (2050-2080). More details on crops can be found in Kolokytha et al. [47].

2. The expansion of the livestock sector as alternative economic activity along with the restructuring of crops (SDS2).

Hay production from alfalfa and livestock crops for the needs of the livestock sector is far more $(280,201.00$ ton/year) than what is needed for the animals $(50,327.51$ ton/year); therefore, there is significant space to enlarge the livestock sector. SDS2 refers to an increase of $20 \%$ of the livestock sector in the Mygdonia Basin based on the report of the Management Body of Lakes Koronia and Volvi. The livestock feed cultivated area, i.e., the alfalfa and the animal feed crops, was proposed to decrease in order to reduce the irrigation water needs in the study area. The maximum acceptable decrease in the livestock feed area was found to be equal to 75\%. In the 2020-2050 period, the minimum decrease in the livestock feed area was estimated to be equal to $62 \%$ for a water surplus of the Mygdonia aquifers to be achieved. In the 2050-2080 period, even the decrease in the livestock feed area at $75 \%$ could not rehabilitate the water deficit of the aquifers; therefore, it was proposed to be accompanied by a reduction in the remaining water-intensive crops in the study area, i.e., maize, tobacco, eastern type tobacco, cotton, sugar beet, sorghum, beans, legumes and potatoes. Of course, the reduction in the irrigated area was projected to decrease the total farm income in the Mygdonia Basin. To compensate for the reduction in rural income, the cut of the irrigated area was proposed to be implemented along with a promotion of crops providing a high net income for farmers so that the economic component of sustainability was also met. The plantation of energy crops for biofuels production, which are projected to be greatly competitive in the future according to European adaptation policies, was tested for the restructuring of crops. Among nine energy crops that were examined in terms of the suitable climate and soil conditions, the irrigation requirements, the harvest period and the net income provided to farmers, cardoon is the most suitable one regarding the climatic and environmental conditions of the study area. This particular crop is highly resistant to the Mediterranean climate (high durability in the low temperatures of the Mediterranean winter, high adaptability to arid conditions with prolonged periods of drought) and provides a high net farm income, about 76,533.33 EUR $/ \mathrm{km}^{2} /$ year. In particular, cardoon and cereals (rain-fed crops) that improve the food security of the study area were proposed to be promoted.

3. A combination of the promotion of drip irrigation systems, along with the restructuring of crops (SDS3). SDS3 concerns the promotion of drip irrigation systems in maize crop cultivation. The future water deficit of the Mygdonia aquifers could not be rehabilitated, even if this measure would be applied throughout the whole Mygdonia Basin. Therefore, the area of the water-intensive crops mentioned in SDS2 needs to be reduced. In the 2020-2050 and 2050-2080 periods, the minimum required decrease in the area of these crops was found to be equal to $35 \%$ and $66 \%$, respectively, for the restoration of the Mygdonia aquifers to be achieved. The drip irrigation systems were proposed to be installed at $25 \%$ and $35 \%$ of the maize cultivated area during the 2020-2050 and 2050-2080 periods, respectively. For the compensation of the farm income loss, crops that provide high net farm income, such as vegetables, potatoes and cardoon, were proposed to be promoted, along with cereals.

The future water balances of the Mygdonia aquifers and Lakes Koronia and Volvi under the Sustainable Development Strategies are presented in Tables 4-9. 
Table 4. Average annual water balance of the Mygdonia aquifers for the 2020-2050 period under the SDS1, SDS2, SDS3.

\begin{tabular}{|c|c|c|c|c|}
\hline 2020-2050 Period & No-Action Scenario & SDS1 & SDS2 & SDS3 \\
\hline \multicolumn{5}{|c|}{ Inflows to Mygdonia aquifers ( $\mathrm{hm}^{3} /$ year) } \\
\hline Recharge & 112.68 & 112.68 & 112.68 & 112.68 \\
\hline Return flow of the pumped water for irrigation use & 27.12 & 18.29 & 18.19 & 18.07 \\
\hline Inflow from Lake Koronia & 0.00 & 0.00 & 0.00 & 0.00 \\
\hline Inflow from Lake Volvi & 1.75 & 0.71 & 0.75 & 0.73 \\
\hline Inflow from the neighbouring groundwater aquifer & 0.00 & 0.00 & 0.00 & 0.00 \\
\hline \multicolumn{5}{|c|}{ Outflows from Mygdonia aquifers $\left(\mathrm{hm}^{3} /\right.$ year) } \\
\hline Outflow for agricultural use & 178.38 & 119.50 & 118.86 & 118.06 \\
\hline Outflow for industrial use & 0.73 & 0.73 & 0.73 & 0.73 \\
\hline Outflow for livestock use & 1.86 & 1.86 & 2.07 & 1.86 \\
\hline Outflow for household use & 6.40 & 6.40 & 6.40 & 6.40 \\
\hline Outflow for tourist use & 0.02 & 0.02 & 0.02 & 0.02 \\
\hline Outflow to Lake Koronia & 0.00 & 0.00 & 0.00 & 0.00 \\
\hline Outflow to Lake Volvi & 0.06 & 0.52 & 0.48 & 0.49 \\
\hline Outflow to the neighbouring groundwater aquifer & 1.15 & 1.80 & 1.75 & 1.74 \\
\hline Water balance of the Mygdonia aquifers ( $\mathrm{hm}^{3} /$ year) & -47.05 & +0.85 & +1.31 & +2.18 \\
\hline
\end{tabular}

Table 5. Average annual water balance of the Mygdonia aquifers for the 2050-2080 period under the SDS1-3.

\begin{tabular}{|c|c|c|c|c|}
\hline 2050-2080 Period & No-Action Scenario & SDS1 & SDS2 & SDS3 \\
\hline \multicolumn{5}{|c|}{ Inflows to Mygdonia aquifers $\left(\mathrm{hm}^{3} /\right.$ year $)$} \\
\hline Recharge & 75.50 & 75.50 & 75.50 & 75.50 \\
\hline Return flow of the pumped water for irrigation use & 29.30 & 11.67 & 11.58 & 11.49 \\
\hline Inflow from Lake Koronia & 0.00 & 0.00 & 0.00 & 0.00 \\
\hline Inflow from Lake Volvi & 2.76 & 0.32 & 0.35 & 0.34 \\
\hline Inflow from the neighbouring groundwater aquifer & 0.80 & 0.00 & 0.00 & 0.00 \\
\hline \multicolumn{5}{|c|}{ Outflows from Mygdonia aquifers ( $\mathrm{hm}^{3} /$ year) } \\
\hline Outflow for agricultural use & 192.91 & 75.38 & 74.82 & 74.20 \\
\hline Outflow for industrial use & 0.73 & 0.73 & 0.73 & 0.73 \\
\hline Outflow for livestock use & 1.86 & 1.86 & 2.07 & 1.86 \\
\hline Outflow for household use & 6.40 & 6.40 & 6.40 & 6.40 \\
\hline Outflow for tourist use & 0.02 & 0.02 & 0.02 & 0.02 \\
\hline Outflow to Lake Koronia & 0.00 & 0.00 & 0.00 & 0.00 \\
\hline Outflow to Lake Volvi & 0.00 & 1.16 & 1.06 & 1.05 \\
\hline Outflow to the neighbouring groundwater aquifer & 0.02 & 1.74 & 1.61 & 1.59 \\
\hline Water balance of the Mygdonia aquifers ( $\mathrm{hm}^{3} /$ year) & -93.58 & +0.20 & +0.72 & +1.48 \\
\hline
\end{tabular}


Table 6. Average annual water balance of the Lake Koronia for the 2020-2050 period under the SDS1-3.

\begin{tabular}{ccccc}
\hline 2020-2050 Period & No-Action Scenario & SDS1 & SDS2 & SDS3 \\
\hline Direct precipitation & Inflows to Lake Koronia $\left(\mathrm{hm}^{3} /\right.$ year) & & & \\
\hline Runoff from the watershed & 18.76 & 18.76 & 18.76 & 18.76 \\
\hline Inflow from the groundwater aquifer & 14.48 & 14.48 & 14.48 & 0.00 \\
\hline Eutflows from Lake Koronia $\left(\mathrm{hm}^{3} /\right.$ year) & 34.21 & 34.21 & 0.00 \\
\hline Pumping from the lake & 34.21 & 0.00 & 34.21 \\
\hline Outflow to the groundwater aquifer & 0.00 & 0.00 & 0.00 \\
\hline Overflow to the Derveni stream & 0.00 & 0.00 & 0.00 \\
\hline Water balance of the Lake Koronia $\left(\mathrm{hm}^{3} /\right.$ year) & 0.00 & 0.00 & 0.00 \\
\hline
\end{tabular}

Table 7. Average annual water balance of the Lake Koronia for the 2050-2080 period under the SDS1-3.

\begin{tabular}{|c|c|c|c|c|}
\hline 2050-2080 Period & No-Action Scenario & SDS1 & SDS2 & SDS3 \\
\hline \multicolumn{5}{|c|}{ Inflows to Lake Koronia $\left(\mathrm{hm}^{3} /\right.$ year) } \\
\hline Direct precipitation & 15.89 & 15.89 & 15.89 & 15.89 \\
\hline Runoff from the watershed & 10.60 & 10.60 & 10.60 & 10.60 \\
\hline Inflow from the groundwater aquifer & 0.00 & 0.00 & 0.00 & 0.00 \\
\hline \multicolumn{5}{|c|}{ Outflows from Lake Koronia $\left(\mathrm{hm}^{3} /\right.$ year $)$} \\
\hline Evaporation & 26.81 & 26.81 & 26.81 & 26.81 \\
\hline Pumping from the lake & 0.00 & 0.00 & 0.00 & 0.00 \\
\hline Outflow to the groundwater aquifer & 0.00 & 0.00 & 0.00 & 0.00 \\
\hline Overflow to the Derveni stream & 0.00 & 0.00 & 0.00 & 0.00 \\
\hline Water balance of the Lake Koronia $\left(\mathrm{hm}^{3} /\right.$ year $)$ & -0.32 & -0.32 & -0.32 & -0.32 \\
\hline
\end{tabular}

Table 8. Average annual water balance of the Lake Volvi for the 2020-2050 period under the SDS1-3.

\begin{tabular}{|c|c|c|c|c|}
\hline 2020-2050 Period & No-Action Scenario & SDS1 & SDS2 & SDS3 \\
\hline \multicolumn{5}{|c|}{ Inflows to Lake Volvi (hm³ / year) } \\
\hline Direct precipitation & 30.50 & 30.50 & 30.50 & 30.50 \\
\hline Runoff from the watershed & 15.62 & 15.62 & 15.62 & 15.62 \\
\hline Inflow from the groundwater aquifer & 0.06 & 0.52 & 0.48 & 0.49 \\
\hline Inflow from the Derveni stream & 0.00 & 0.00 & 0.00 & 0.00 \\
\hline \multicolumn{5}{|c|}{ Outflows from Lake Volvi ( $\mathrm{hm}^{3} /$ year) } \\
\hline Evaporation & 45.70 & 46.68 & 46.62 & 46.65 \\
\hline Pumping from the lake & 2.40 & 2.40 & 2.40 & 2.40 \\
\hline Outflow to the groundwater aquifer & 1.75 & 0.71 & 0.75 & 0.73 \\
\hline Overflow to the Richios stream & 0.00 & 0.00 & 0.00 & 0.00 \\
\hline Water balance of the Lake Volvi ( $\mathrm{hm}^{3} /$ year) & -3.67 & -3.15 & -3.17 & -3.17 \\
\hline
\end{tabular}


Table 9. Average annual water balance of the Lake Volvi for the 2050-2080 period under the SDS1-3.

\begin{tabular}{|c|c|c|c|c|}
\hline 2050-2080 Period & No-Action Scenario & SDS1 & SDS2 & SDS3 \\
\hline \multicolumn{5}{|c|}{ Inflows to Lake Volvi ( $\mathrm{hm}^{3}$ /year) } \\
\hline Direct precipitation & 25.58 & 25.58 & 25.58 & 25.58 \\
\hline Runoff from the watershed & 12.94 & 12.94 & 12.94 & 12.94 \\
\hline Inflow from the groundwater aquifer & 0.00 & 1.16 & 1.06 & 1.05 \\
\hline Inflow from the Derveni stream & 0.00 & 0.00 & 0.00 & 0.00 \\
\hline \multicolumn{5}{|c|}{ Outflows from Lake Volvi (hm³ /year) } \\
\hline Evaporation & 36.19 & 39.59 & 39.47 & 39.48 \\
\hline Pumping from the lake & 2.40 & 2.40 & 2.40 & 2.40 \\
\hline Outflow to the groundwater aquifer & 2.76 & 0.32 & 0.35 & 0.34 \\
\hline Overflow to the Richios stream & 0.00 & 0.00 & 0.00 & 0.00 \\
\hline Water balance of the Lake Volvi $\left(\mathrm{hm}^{3}\right.$ /year) & -2.83 & -2.63 & -2.64 & -2.65 \\
\hline
\end{tabular}

Analysis of the Results

All three Sustainable Development Strategies are projected to achieve a water surplus of the Mygdonia Basin for both the short-term and long-term future periods. Tables 4 and 5 shows that the significant reduction of discharge for agricultural use is the main reason for the quantitative rehabilitation of the basin. The restructuring of the agricultural sector is proposed to be more intense in the 2050-2080 period compared with the 2020-2050 period in order to compensate for the larger decrease in the recharge to aquifers during the long-term future period. In particular, in the 2020-2050 period, the outflow from Mygdonia aquifers for agricultural use is projected to decrease from $178.38 \mathrm{hm}^{3} /$ year in the no-action scenario to $119.50 \mathrm{hm}^{3} /$ year $(-33.00 \%)$ in SDS1, $118.86 \mathrm{hm}^{3} /$ year $(-33.37 \%)$ in SDS2 and $118.06 \mathrm{hm}^{3} /$ year $(-33.82 \%)$ in SDS3. Furthermore, in the 2050-2080 period, the water withdrawals from the Mygdonia aquifers for irrigation are projected to decrease from $192.91 \mathrm{hm}^{3} /$ year in the no-action scenario to $75.38 \mathrm{hm}^{3} /$ year $(-60.92 \%)$ in SDS1, $74.82 \mathrm{hm}^{3} /$ year $(-61.22 \%)$ in SDS2 and $74.20 \mathrm{hm}^{3} /$ year $(-61.54 \%)$ in SDS3. The improvement of the water availability of the Mygdonia aquifers is not projected to have a positive effect on the water balance of Lake Koronia (Tables 6 and 7 due to the impermeable bottom of Lake Koronia [68], preventing any water flow exchange between the lake and the aquifers. Moreover, the quantitative rehabilitation of the Mygdonia aquifers is projected to increase the water inflow from the Mygdonia aquifers to Lake Volvi and to decrease the water outflow from the lake to aquifers, resulting in an increase in evaporative losses due to the increase of the water availability and surface area of the lake and, finally, to the slight improvement of the water balance of Lake Volvi, as shown in Tables 8 and 9.

In terms of economic sustainability (rural income), the implementation of the fallow land scheme in SDS1 is expected to cause a decrease in the total net farm income in the Mygdonia Basin from 45,773,037.90 EUR/year (no-action scenario) to 35,395,528.60 EUR/year in 2020-2050 and 26,587,206.00 EUR/year in 2050-2080. A compensatory policy in the form of offsets may be a good option.

Increasing livestock farming while reducing alfalfa farming (water-intensive cultivation) and promoting energy crops proposed in SDS2 provide a competitive alternative growth option that is expected to increase the total net farm income from 45,773,037.90 EUR/year (no-action scenario) to 46,194,872.34 EUR/year (+0.92\%) in 2020-2050 and 45,901,602.53 EUR/year $(+0.28 \%)$ in 2050-2080. This strategy is capable of successfully managing the groundwater aquifer deficit. The promotion of drip irrigation systems, along with the crops restructuring proposed in SDS3, is expected to provide a small increase to the farmers' net income from 45,773,037.90 EUR/year (no-action scenario) to 46,267,432.24 EUR/year (+1.08\%) in 2020-2050 and 45,971,157.73 EUR/year (+0.43\%) in 2050-2080. 
Another adaptation scenario based on the European Energy Roadmap 2050 concerned the exploitation of the wind potential, with the installation of wind farms to produce "green" electric energy that can be used in pumping wells for irrigation. The land-use feasibility and economic viability of this plan were examined using the "Greek Special Framework for Spatial Planning for Renewable Energy Sources", which is the main legislative instrument for establishing wind farms according to land-use criteria. It provides criteria and guidelines for the site allocation of RES projects with an emphasis on wind systems and ensures the sustainability of RES investments through their harmonious incorporation within the natural and human environment. The combination of 10 environmental, 1 technical, 5 economic and 3 social criteria resulted in the determination of an eligible area for establishing wind farms based on land-use criteria. The future wind potential of the Mygdonia Basin was estimated using the monthly wind speed projections at a height of $10 \mathrm{~m}$ above the surface. The future wind speed data were derived from the SMHIRCA climate model under the IPCC SRES A1B with a spatial resolution of almost $25 \mathrm{~km}$. The annual wind speed in the whole basin at a $10 \mathrm{~m}$ height above the surface was found to be less than $4 \mathrm{~m} / \mathrm{s}$, which is insufficient since this wind speed is lower than the cut-in speed of wind turbines. The installation of wind turbines at heights of 80,100,120 and $140 \mathrm{~m}$ above the surface was examined. Finally, it was found that wind turbines should be established at a height of $140 \mathrm{~m}$ above the surface, where the generated electric energy by wind was found to be a non-economically viable plan since the total cost of the installation of the wind turbines was estimated to be far more expensive than that from conventional resources to be used in pumping wells for irrigation. Details on the methodology can be found in [66].

\section{Discussion}

Mygdonia Basin is a typical Mediterranean agricultural highly negative basin in terms of water balance. This study aimed to summarize and assess potential adaptation measures to reverse the unsustainable water management as a combination of different strategies, which were formed by taking into account both the hydrology of the basin; socioeconomic conditions; environmental parameters; and several international, national, regional and local policies. Sustainable strategies for the restoration of the water bodies in Mygdonia Basin for the 2020-2050 and 2050-2080 periods were tested as adaptation solutions. In addition, the economic effects on the farmers' incomes were estimated for each of the proposed strategies.

It was confirmed that in cases of drained water basins, such as Mygdonia Basin, the efficacy of measures that will only reduce/limit the use of water does not provide a sustainable solution to the problem.

Of all the combined strategies, the most effective one that could guarantee the restoration of both the aquifer and the lakes and assure the sustainability of the water system is the drastic suspension of the agricultural sector. Concurrently, the expansion of alternative competitive economic activities that are capable of maintaining the income of the inhabitants and ensuring the sustainability and protection of water resources was proposed. More specifically, the implementation of a fallow land measure, as well as the promotion of rain-fed or low-water-intensive crops, in combination with the promotion of drip irrigation systems, was found to be the ideal solution for sustainable water management and development in the area under study.

Highly water-stressed hydrological basins, such as Mygdonia Basin, which are also found in other Mediterranean countries, can only be restored if there are drastic reductions in economic water-consuming activities, such as agriculture, or a shift to other new economic activities that are compatible with the new climate conditions.

Generally, the new ominous climate context calls for a new approach. The development of a new "social calculus" that would enable the water community to not only meet present crises but also consider the meaning of our actions in the context of long-range plans could be feasible and sustainable in the future. The change in perception of how water 
should be treated in all uses is the key to sustainable water management. In the case of farmers, irrigation efficiency is most of the time synonymous with maximizing net revenue rather than saving water. Even in cases of limited supplies, water-saving is not a priority for most farmers. Although innovative irrigation technologies are at the forefront of the solution in saving water in agriculture, labor and other inputs to get better economic gains are the main concern of farmers who make irrigation decisions by relying mostly on their practical experience. The selection of crops used to be related to subsidies coming from the EU, which resulted in the depletion of water resources in many basins with water problems, as water-intensive consuming crops were chosen (cotton, rice, etc.). In such cases, the development of local irrigation advisory services, education and training programs are important and should be considered by the relevant authorities. Farmers generally lack adequate assistance to develop and adopt better approaches and need better technical advice.

Adaptation goes beyond traditional coordination between agencies, interactions between water uses and planning approaches that consider all possible strategies and impacts. It is an integral part of a region's social and economic development. It refers to a norm-shifting change in management and policy that is mainly focused on demand management although strategies for adaptation that entail both water supply and water demand management.

The following directions are central for effective adaptation to climate change in water management.

\section{Change the "Orientation" of the Hydraulic Engineering Projects}

Until recently, large infrastructure (dams and reservoirs) were designed and constructed to store excess seasonal water for future use under the condition that the availability of water resources is almost constant over time. Now that we are experiencing a deep change in the pattern of the hydrological cycle with the more frequent occurrence of extreme events and a severe decrease in water reserves, this option can no longer satisfy water demand and competing needs. Adaptive management with regard to hydraulic engineering projects means managing the consequences of extreme events, i.e., the frequent interchange of the period of droughts and floods. More specifically, groundwater recharge management and managed aquifer recharge (MAR) [72-74] are among the most effective engineering techniques. The constant decrease in precipitation and runoff requires a new orientation of water storage engineering projects that will manage the new water deficits. These techniques include the use of treated wastewater for aquifer storage [73-76]. Furthermore, changes in the hydrology of a basin in relation to changes in social values may result in new uses for reservoir storage, which may have greater economic or social value. Of course, high uncertainty in future projections for water availability poses a threat to the accuracy of projections.

Moreover, the adoption of an integrated approach is required to manage the consequences of natural disasters (fires, droughts and floods) in terms of providing proactive measures to prevent disasters and shield natural systems, such as through fire protection, control of forest fires, erosion prevention and flood control projects.

Given that interventions in existing infrastructure to enhance water resources have limited potential, due to climate projections that predict a decrease in rainfall, the only effective and sustainable way out is to adopt demand management methods and measures. Demand management measures consist of a great array of techniques and tools (engineering, economic, environmental, institutional and social). Demand management may be applied through the implementation of strict standards in terms of water use and appropriate legislation to limit and control illegal drilling. In Mediterranean countries, such as France, Portugal, Italy and Spain, they have implemented different tax systems on agricultural water abstractions to recover the costs of the regulation, storage and management of basin-level water services with various levels of cost recovery in accordance with the provision in the Water Framework Directive. Meanwhile, incentives, such as tax reduction, would encourage water saving in all uses. Technical interventions to reduce losses in irriga- 
tion networks and water efficiency advantages through education and training campaigns on farms are among the options. Economic instruments, such as water metering and water pricing, are critical but very difficult to be implemented, first, because there is a high initial cost for metering that needs to be subsided by the authorities and, second, because the appropriate pricing policy needs detailed analysis that takes into account socioeconomic constraints, among others, which, for the moment in Greece, is still in the early stage. Educating water users, giving access to data and strengthening the cooperation between academia and industry are also important elements for successful demand management.

All the measures are location- and case-specific since adaptation is more effective at the local level. In the areas most vulnerable to climate change, emphasis is given to socioeconomic development and robust agricultural management. Sometimes it is wise to make a combination of adopting traditional techniques of water storage (cisterns) and traditional cultivations, which are already well known to farmers, with the use of modern technology to achieve water conservation. Moreover, the choice of crops and crop pattern in the case of irrigated agriculture should be compatible with the climatic conditions of the area and the land (soil). More efficient irrigation systems, shifts toward less water-intensive or more drought-tolerant crops, application of deficit irrigation schemes, land reclamation and land management for carbon sequestration [77-80] may reduce water needs for agriculture and increase water-use efficiency $[27,75]$. The yearly water withdrawal for irrigation in the Mediterranean region amounts to $\sim 223 \mathrm{~km}^{3}$ [81], but there is a great water saving potential through the implementation of efficient irrigation systems [82-84]. The rebound effect should be mentioned though, as the water-saving effect of efficient irrigation systems may be counterbalanced by the expansion of irrigated areas $[63,85,86]$.

\section{Conclusions}

Generally, highly water-stressed hydrological basins, such as Mygdonia Basin, which are also found in other Mediterranean countries, can only be restored if there are drastic reductions in water-consuming economic activities (agriculture) and a change in the development model in such a way to shift to other alternative development plans that are compatible with the new climate conditions.

Although great emphasis must be placed on water management and irrigation efficiency, which is still not done in the best way today (many parts of the country are already facing serious problems), this option alone cannot alleviate the water problems.

The reformation of the development plans in the agricultural sector, which is a global issue, is tightly connected with food security, which should be a priority in every agricultural basin. To assure food security, a set of crops that are compatible with the climate, soil and water requirements of the area under study should be prioritized.

All these interventions/changes should be accompanied by information campaigns for growers and breeders on both the effects of climate change on their work and the tools available to manage these effects. Training is important for implementing new crop diversification and rotation, the selection of crops that are better adapted to the new climatic conditions for the region in question and the targeted drainage of agricultural land.

Above all, political will and governmental engagement are crucial for the adoption of a new development model based on the available water resources and the comparative advantages of each area. In the case of highly water-stressed basins, agriculture should not be a priority. Seeking alternative economic activities that use less water is the best adaptation.

The methodology followed in this research, as well as the proposed sustainable development strategies, could prove very useful, not only for the local authorities in Mygdonia Basin but also for any other river basin with similar characteristics.

Funding: This research received no external funding

Institutional Review Board Statement: Not applicable.

Informed Consent Statement: Not applicable. 
Data Availability Statement: This is an article. Some of the results were published in Malamataris, D.; Kolokytha, E.; Loukas, A. Integrated hydrological modeling of surface water and groundwater under climate change: The case of Mygdonia Basin in Greece, J. Water Clim. Change 2020, 11, 1429-1454. https: / / doi.org/10.2166/wcc.2019.011 (accessed on 27 December 2021), and Kolokytha, E.; Malamataris, D. Integrated Water Management Approach for Adaptation to Climate Change in Highly Water Stressed Basins, Water Resour. Manage. 2020, 34, 1173-1197, https://doi.org/10.1007/s11269-020-02492-w (accessed on 27 December 2021).

Acknowledgments: The results of this research are part of a doctoral thesis (Malamataris 2019), "Integrated water resources management and sustainable development strategy in a changing climate: Case study of the Mygdonia water basin" which was funded by the IKY Fellowships of Excellence for Postgraduate Studies in Greece-Siemens Program. Special thanks to DHI for the kind provision of the software MIKE SHE, MIKE HYDRO River and MIKE HYDRO Basin licenses that were used for the modeling tasks that are mentioned in this paper.

Conflicts of Interest: The author declares no conflict of interest.

\section{References}

1. Koutsoyiannis, D. Hurst-Kolmogorov Dynamics and Uncertainty. JAWRA J. Am. Water Resour. Assoc. 2011, 47, 481-495. [CrossRef]

2. Cook, J.; Oreskes, N.; Doran, P.T.; Anderegg, W.R.L.; Verheggen, B.; Maibach, E.W.; Carlton, J.S.; Lewandowsky, S.; Skuce, A.G.; Green, S.A.; et al. Consensus on Consensus: A Synthesis of Consensus Estimates on Human-Caused Global Warming. Environ. Res. Lett. 2016, 11, 048002. [CrossRef]

3. Lins, H.F.; Cohn, T.A. Stationarity: Wanted Dead or Alive? JAWRA J. Am. Water Resour. Assoc. 2011, 47, 475-480. [CrossRef]

4. Masson-Delmotte, V.; Zhai, P.; Chen, Y.; Goldfarb, L.; Gomis, M.I.; Matthews, J.B.R.; Berger, S.; Huang, M.; Yelekçi, O.; Yu, R.; et al. Working Group I Contribution to the Sixth Assessment Report of the Intergovernmental Panel on Climate Change; Cambridge University Press: Cambridge, UK, 2021.

5. UN Office. UNDRR Global Natural Disaster Assessment Report; UN Annual Report; UN Office: Geneva, Switzerland, 2020.

6. Climate Change IUN-Water. Available online: https://www.unwater.org/water-facts/climate-change/ (accessed on 27 December 2021).

7. Fawzy, S.; Osman, A.I.; Doran, J.; Rooney, D.W. Strategies for Mitigation of Climate Change: A Review. Environ. Chem. Lett. 2020, 18, 2069-2094. [CrossRef]

8. Noble, I.R.; Huq, S.; Anokhin, Y.A.; Carmin, J.A.; Goudou, D.; Lansigan, F.P.; Osman-Elasha, B.; Villamizar, A.; Patt, A.; Takeuchi, K.; et al. Adaptation Needs and Options. In Climate Change 2014: Impacts, Adaptation, and Vulnerability. Part A: Global and Sectoral Aspects; Cambridge University Press: Cambridge, UK, 2014; pp. 833-868.

9. Olmstead, S.M. Climate Change Adaptation and Water Resource Management: A Review of the Literature. Energy Econ. 2014, 46, 500-509. [CrossRef]

10. Bours, D.; Mcginn, C.; Pringle, P. Monitoring \& Evaluation for Climate Change Adaptation: A Synthesis of Tools, Frameworks and Approaches; SEA Change, CoP, Phnom Penh and UKCIP: Oxford, UK, 2013.

11. Smit, B.; Burton, I.; Klein, R.J.T.; Wandel, J. An Anatomy of Adaptation to Climate Change and Variability. Clim. Change 2000, 45, 223-251. [CrossRef]

12. Hallegatte, S. Strategies to Adapt to an Uncertain Climate Change. Glob. Environ. Change 2009, 19, 240-247. [CrossRef]

13. Adger, W.N.; Lorenzoni, I.; O'Brien, K.L. Adapting to Climate Change: Thresholds, Values, Governance; Cambridge University Press: Cambridge, UK, 2009.

14. Salerno, F. Adaptation Strategies for Water Resources: Criteria for Research. Water 2017, 9, 805. [CrossRef]

15. Adger, W.N.; Arnell, N.W.; Tompkins, E.L. Successful Adaptation to Climate Change across Scales. Glob. Environ. Change 2005, 15, 77-86. [CrossRef]

16. Thompson, S.E.; Sivapalan, M.; Harman, C.J.; Srinivasan, V.; Hipsey, M.R.; Reed, P.; Montanari, A.; Blöschl, G. Developing Predictive Insight into Changing Water Systems: Use-Inspired Hydrologic Science for the Anthropocene. Hydrol. Earth Syst. Sci. 2013, 17, 5013-5039. [CrossRef]

17. Pahl-Wostl, C. Transitions towards Adaptive Management of Water Facing Climate and Global Change. Water Resour. Manag. 2007, 21, 49-62. [CrossRef]

18. Medema, W.; Mcintosh, B.S.; Jeffrey, P.J. From Premise to Practice: A Critical Assessment of Integrated Water Resources Management and Adaptive Management Approaches in the Water Sector. Ecol. Soc. 2008, 13, 18. [CrossRef]

19. Wilby, R.L.; Dessai, S. Robust Adaptation to Climate Change. Weather 2010, 65, 180-185. [CrossRef]

20. Kim, Y.O.; Chung, E.S. Adaptation to Climate Change: Decision Making. Sustain. Water Resour. Plan. Manag. Under Clim. Change 2016, 8, 189-221. [CrossRef]

21. AQUASTAT Database Database Query Results. Available online: https://www.fao.org/aquastat/statistics/query/results.html (accessed on 7 December 2021).

22. Sofios, S.; Arabatzis, G.; Baltas, E. Policy for Management of Water Resources in Greece. Environmentalist 2008, 28, 185-194. [CrossRef]

23. Mimikou, M.A. Water Resourses in Greece: Present and Future. Glob. NEST J. 2005, 7, 313-322.

24. Mylopoulos, Y.; Kolokytha, E.; Tolikas, D. Urban Water Management in Greece. Water Int. 2003, 28, 43-51. [CrossRef] 
25. Implementation of River Basin Management Plans-Greece-Environment-European Commission. Available online: https: / / ec.europa.eu/environment/water/participation/map_mc/countries/greece_en.htm (accessed on 8 December 2021).

26. Kondolf, G.M.; Podolak, K.; Grantham, T.E. Restoring Mediterranean-Climate Rivers. Hydrobiologia 2013, 719, 527-545. [CrossRef]

27. Cramer, W.; Guiot, J.; Fader, M.; Garrabou, J.; Gattuso, J.P.; Iglesias, A.; Lange, M.A.; Lionello, P.; Llasat, M.C.; Paz, S.; et al. Climate Change and Interconnected Risks to Sustainable Development in the Mediterranean. Nat. Clim. Change 2018, 8, 972-980. [CrossRef]

28. Barkhordarian, A.; von Storch, H.; Bhend, J. The Expectation of Future Precipitation Change over the Mediterranean Region Is Different from What We Observe. Clim. Dyn. 2013, 40, 225-244. [CrossRef]

29. Giorgi, F.; Lionello, P. Climate Change Projections for the Mediterranean Region. Glob. Planet. Change 2008, 63, 90-104. [CrossRef]

30. Lionello, P.; Scarascia, L. The Relation between Climate Change in the Mediterranean Region and Global Warming. Reg. Environ. Change 2018, 18, 1481-1493. [CrossRef]

31. Toreti, A.; Naveau, P.; Zampieri, M.; Schindler, A.; Scoccimarro, E.; Xoplaki, E.; Dijkstra, H.A.; Gualdi, S.; Luterbacher, J.; Naveau, P.; et al. Projections of Global Changes in Precipitation Extremes from Coupled Model Intercomparison Project Phase 5 Models. Geophys. Res. Lett. 2013, 40, 4887-4892. [CrossRef]

32. Toreti, A.; Naveau, P. On the Evaluation of Climate Model Simulated Precipitation Extremes. Environ. Res. Lett. 2015, 10, 014012. [CrossRef]

33. Garrote, L.; Iglesias, A.; Granados, A.; Mediero, L.; Martin-Carrasco, F. Quantitative Assessment of Climate Change Vulnerability of Irrigation Demands in Mediterranean Europe. Water Resour. Manag. 2015, 29, 325-338. [CrossRef]

34. Charles, H.; Godfray, H.; Garnett, T. Food Security and Sustainable Intensification. Philos. Trans. R. Soc. B Biol. Sci. 2014, 369. [CrossRef]

35. Döll, P.; Jiménez-Cisneros, B.; Oki, T.; Arnell, N.W.; Benito, G.; Cogley, J.G.; Jiang, T.; Kundzewicz, Z.W.; Mwakalila, S.; Nishijima, A. Integrating Risks of Climate Change into Water Management. Hydrol. Sci. J. 2014, 60, 4-13. [CrossRef]

36. World Resource Institut, RELEASE: Updated Global Water Risk Atlas Reveals Top Water-Stressed Countries and States. 2019. Available online: https://www.wri.org/news/release-updated-global-water-risk-atlas-reveals-top-water-stressed-countriesand-states (accessed on 27 December 2021).

37. Climate Change Impact Scientific Committee (CCISC). The Environmental, Economic and Social Impacts of Climate Change in Greece; Bank of Greece: Athens, Greece, 2011.

38. Tsiros, I.X.; Nastos, P.; Proutsos, N.D.; Tsaousidis, A. Variability of the Aridity Index and Related Drought Parameters in Greece Using Climatological Data over the Last Century (1900-1997). Atmos. Res. 2020, 240, 104914. [CrossRef]

39. Kourgialas, N.N.; Anyfanti, I.; Karatzas, G.P.; Dokou, Z. An Integrated Method for Assessing Drought Prone Areas-Water Efficiency Practices for a Climate Resilient Mediterranean Agriculture. Sci. Total Environ. 2018, 625, 1290-1300. [CrossRef]

40. Kourgialas, N.N. A Critical Review of Water Resources in Greece: The Key Role of Agricultural Adaptation to Climate-Water Effects. Sci. Total Environ. 2021, 775, 145857. [CrossRef]

41. Nastos, P.T.; Zerefos, C.S. Spatial and Temporal Variability of Consecutive Dry and Wet Days in Greece. Atmos. Res. 2009, 94, 616-628. [CrossRef]

42. Nastos, P.T.; Kapsomenakis, J. Regional Climate Model Simulations of Extreme Air Temperature in Greece. Abnormal or Common Records in the Future Climate? Atmos. Res. 2015, 152, 43-60. [CrossRef]

43. The Impact of Climate Change on the Greek Economy-Dianeosis. Available online: https://www.dianeosis.org/en/2017/08/ impact-climate-change-greek-economy/ (accessed on 8 December 2021).

44. Environplan, S.A. Regional Adaptation Plan to Climate Change in Central Macedonia; Technical Report for Thessaloniki: Thessaloniki, Greece, 2021.

45. Bobori, D.; Tsavdaroglou, F.; Bafeiadou, A.; Patsia, A.; Karta, E.; Kravva, M.; Tekidis, E.; Koulogiannis, S.; Avramidis, A.; Poulia, A.; et al. Annual Report of the Management Body of Lakes Koronia and Volvi; Technical Report for the Management Body of Lakes Koronia and Volvi: Lagkadas, Greece, 2016; p. 35. (In Greek)

46. Veranis, N. Hydrogeological Study of Mygdonias, Mavroudas, Agiou Orous, Xolomonta, Olympiadas, Asprolakka, Ierissou, and Rodon Groundwater Systems; Technical Report for Groundwater Systems: Thessaloniki, Greece, 2010. (In Greek)

47. Malamataris, D.; Kolokytha, E.; Loukas, A. Integrated Hydrological Modelling of Surface Water and Groundwater under Climate Change: The Case of the Mygdonia Basin in Greece. J. Water Clim. Change 2020, 11, 1429-1454. [CrossRef]

48. Greek Ministry of the Environment. Energy and Climate Change, Analysis of Pressures and Impacts on Water Resources; Technical Report for Greek Ministry of the Environment: Athens, Greece, 2020; p. 212. (In Greek)

49. Kolokytha, E.; Malamataris, D. Integrated Water Management Approach for Adaptation to Climate Change in Highly Water Stressed Basins. Water Resour. Manag. 2020, 34, 1173-1197. [CrossRef]

50. Malamataris, D.; Kolokytha, E.; Mylopoulos, I.; Loukas, A. Critical Review of Adaptation Strategies for the Restoration of Lake Koronia. Eur. Water 2017, 58, 203-208.

51. Gantidis, N.; Pervolarakis, M.; Fytianos, K. Assessment of the Quality Characteristics of Two Lakes (Koronia and Volvi) of N Greece. Environ. Monit. Assess. 2007, 125, 175-181. [CrossRef]

52. Perivolioti, T.; Doxani, G.; Bobori, D.; Perivolioti, T.-M.; Mouratidis, A. Monitoring the water quality of lake koronia using long time-series of multispectral satellite images remote sensing (mdpi) journal: Special issue "remote sensing of soil erosion" view project sentinel-2 view project monitoring the water quality of lake koronia using long time-series of multispectral satellite images. AUC Geogr. Praha Czech Repub. 2016, 54124, 9-13.

53. Zacharias, I.; Bertachas, I.; Skoulikidis, N.; Koussouris, T. Greek Lakes: Limnological Overview. Lakes Reserv. Res. Manag. 2002, 7, 55-62. [CrossRef] 
54. Christophoridis, C.; Fytianos, K. Conditions Affecting the Release of Phosphorus from Surface Lake Sediments. J. Environ. Qual. 2006, 35, 1181-1192. [CrossRef]

55. Petaloti, C.; Voutsa, D.; Samara, C.; Sofoniou, M.; Stratis, I.; Kouimtzis, T. Nutrient Dynamics in Shallow Lakes of Northern Greece. Environ. Sci. Pollut. Res. 2004, 11, 11-17. [CrossRef]

56. Moustaka-Gouni, M.; Michaloudi, E.; Kormas, K.; Katsiapi, M.; Moustaka-Gouni, M.; Michaloudi, E.; Kormas, K.A.; Katsiapi, M.; Vardaka, E.; Genitsaris, S. Plankton Changes as Critical Processes for Restoration Plans of Lakes Kastoria and Koronia Dietary Supplements of Spirulina: Apart from Knowing Benefits Are Any Hidden Treats? View Project LAKEREMAKE View Project 76 PUBLICATIONS 1328 CITATIONS SEE PROFILE Plankton Changes as Critical Processes for Restoration Plans of Lakes Kastoria and Koronia. Eur. Water 2012, 40, 43-51.

57. Manakou, V.; Tsiakis, P.; Kungolos, A. A Mathematical Programming Approach to Restore the Water Balance of the Hydrological Basin of Lake Koronia. Desalination Water Treat. 2013, 51, 2955-2976. [CrossRef]

58. Zalidis, G. Environmental Rehabilitation Plan of Lake Koronia and the Greater Area of Mygdonia Basin; Technical Report for Thessaloniki: Thessaloniki, Greece, 2004. (In Greek)

59. Zalidis, G.; Alexandridis, T. Revised Restoration Plan of Lake Koronia; Technical Report for Thessaloniki: Thessaloniki, Greece, 2004. (In Greek)

60. Kolokytha, E. European Policies for Confronting Yhe Challenges of Climate Change in Water Resources. Curr. Sci. 2010, 98, 1069-1076.

61. Kolokytha, E. Agricultural Development in Lake Koronia. The Role of the Water Footprint of Major Crops in Combating Climate Change. In Proceedings of the 3rd IAHR Europe Congress, Porto, Portugal, 14-16 April 2014.

62. Kolokytha, E.; Ntota, A.; Mylopoulos, I. Impact of Climate Change Un Greece-The Lake Koronia Case. In Proceedings of the 33rd Inrernational Congress IHAR, e-Proceedings, Vancouver, BC, Canada, 9-14 August 2009.

63. Oishi, S.; Teegavarapu, R.S.V. Sustainable Water Resources Planning and Management under Climate Change; Springer: Singapore, 2016; ISBN 9789811020513.

64. Mylopoulos, N.; Mylopoulos, Y.; Kolokytha, E.; Tolikas, D. Integrated Water Management Plans for the Restoration of Lake Koronia, Greece. Water Int. 2011, 32, 720-738. [CrossRef]

65. Mylopoulos, I.; Tolikas, D.; Mylopoulos, N.; Zorba, A.; Palaiologos, V.; Kolokytha, E.; Mentes, A.; Karamanlidou, M. Study of the Exploitation Potential of the Deep Aquifer of the Lake Koronia sub-Catchment in the Prefecture of Thessaloniki; Technical Report for Thessaloniki: Thessaloniki, Greece, 2002; p. 183. (In Greek)

66. Malamataris, D.; Kolokytha, E.; Loukas, A.; Mylopoulos, Y. "Green" Energy in the Framework of the Sustainable Development of the Mygdonia Basin, Greece. In Proceedings of the 7th International Conferenceon Environmental Management, Engineering, Planning, and Economics CEMEPE \& SECOTOX Conference, Mykonos, Greece, 19-24 May 2019.

67. Loukas, A.; Mylopoulos, N.; Vasiliades, L. A Modeling System for the Evaluation of Water Resources Management Strategies in Thessaly, Greece. Water Resour. Manag. 2007, 21, 1673-1702. [CrossRef]

68. Sidiropoulos, P.; Mylopoulos, N.; Loukas, A. Optimal Management of an Overexploited Aquifer under Climate Change: The Lake Karla Case. Water Resour. Manag. Int. J. Publ. Eur. Water Resour. Assoc. (EWRA) 2013, 27, 1635-1649. [CrossRef]

69. Danish Hydraulic Institut (DHI), MIKE SHE Documentation. Available online: https://manuals.mikepoweredbydhi.help/2017 /MIKE_SHE.htm (accessed on 7 December 2021).

70. Danish Hydraulic Institut (DHI), MIKE HYDRO Documentation. Available online: https:/ / manuals.mikepoweredbydhi.help/20 17/MIKE_Hydro.htm (accessed on 7 December 2021).

71. Danish Hydraulic Institut (DHI), MIKE HYDRO, Basin User Guide. Available online: https:/ / www.mikepoweredbydhi.com/ products / mike-hydro-basin (accessed on 7 December 2021).

72. Zhang, H.; Xu, Y.; Kanyerere, T. A Review of the Managed Aquifer Recharge: Historical Development, Current Situation and Perspectives. Phys. Chem. Earth Parts A/B/C 2020, 118-119, 102887. [CrossRef]

73. Dillon, P.; Pavelic, P.; Page, D.; Beringen, H.; Ward, J. Managed Aquifer Recharge, an Introduction; No.13 Series; CSIRO on behalf of National Water Commission: Canberra, Australia, 2009.

74. Dillon, P.; Arshad, M. Managed Aquifer Recharge in Integrated Water Resource Management. In Integrated Groundwater Management Concepts, Approaches and Challenges; Springer: Cham, Switzerland, 2016; pp. 435-452. [CrossRef]

75. Djuma, H.; Bruggeman, A.; Eliades, M.; Lange, M.A. Non-Conventional Water Resources Research in Semi-Arid Countries of the Middle East. Desalination Water Treat. 2016, 57, 2290-2303. [CrossRef]

76. Barnett, S.R.; Howles, S.R.; Martin, R.R.; Gerges, N.Z. Aquifer Storage and Recharge: Innovation in Water Resources Management. Aust. J. Earth Sci. 2000, 47, 13-19. [CrossRef]

77. Missimer, T.M.; Drewes, J.E.; Amy, G.; Maliva, R.G.; Keller, S. Restoration of Wadi Aquifers by Artificial Recharge with Treated Waste Water. Ground Water 2012, 50, 514-527. [CrossRef] [PubMed]

78. Ghaffour, N.; Missimer, T.M.; Amy, G.L. Combined Desalination, Water Reuse, and Aquifer Storage and Recovery to Meet Water Supply Demands in the GCC/MENA Region. Desalination Water Treat. 2013, 51, 38-43. [CrossRef]

79. Nikolaou, G.; Neocleous, D.; Christou, A.; Kitta, E.; Katsoulas, N. Implementing Sustainable Irrigation in Water-Scarce Regions under the Impact of Climate Change. Agronomy 2020, 10, 1120. [CrossRef] 
80. Almagro, M.; de Vente, J.; Boix-Fayos, C.; García-Franco, N.; Melgares de Aguilar, J.; González, D.; Solé-Benet, A.; Martínez-Mena, M. Sustainable Land Management Practices as Providers of Several Ecosystem Services under Rainfed Mediterranean Agroecosystems. Mitig. Adapt. Strateg. Glob. Change 2016, 21, 1029-1043. [CrossRef]

81. Fader, M.; Giupponi, C.; Burak, S.; Dakhlaoui, H.; Koutroulis, A.; Lange, M.A.; Llasat, M.C.; Pulido-Velazquez, D.; Sanz-Cobeña, A. Water. In Climate and Environmental Change in the Mediterranean Basin-Current Situation and Risks for the Future. First Mediterranean Assessment Report; Cramer, W., Guiot, J., Marini, K., Eds.; Union for the Mediterranean, Plan Bleu, UNEP/MAP: Marseille, France, 2020.

82. Fader, M.; Shi, S.; von Bloh, W.; Bondeau, A.; Cramer, W. Mediterranean Irrigation under Climate Change: More Efficient Irrigation Needed to Compensate for Increases in Irrigation Water Requirements. Hydrol. Earth Syst. Sci. 2016, 20, 953-973. [CrossRef]

83. Harmanny, K.S.; Malek, Ž. Adaptations in Irrigated Agriculture in the Mediterranean Region: An Overview and Spatial Analysis of Implemented Strategies. Reg. Environ. Change 2019, 19, 1401-1416. [CrossRef]

84. Fishman, R.; Devineni, N.; Raman, S. Can Improved Agricultural Water Use Efficiency Save India's Groundwater? Environ. Res. Lett. 2015, 10, 084022. [CrossRef]

85. Song, J.; Guo, Y.; Wu, P.; Sun, S.H. The Agricultural Water Rebound Effect in China. Ecol. Econ. 2018, 146, 497-506. [CrossRef]

86. Paul, C.; Techen, A.K.; Robinson, J.S.; Helming, K. Rebound Effects in Agricultural Land and Soil Management: Review and Analytical Framework. J. Clean. Prod. 2019, 227, 1054-1067. [CrossRef] 